\title{
Early Performance of Jujube Drying and Multipurpose Cultivars in the Southwestern United States
}

\author{
Shengrui Yao \\ Department of Plant and Environmental Sciences, New Mexico State \\ University, Las Cruces, NM 88003; and Sustainable Agriculture Science \\ Center at Alcalde, New Mexico State University, Alcalde, NM 87511
}

\author{
Robert Heyduck \\ Sustainable Agriculture Science Center at Alcalde, New Mexico State \\ University, Alcalde, NM 87511
}

\section{Steven Guldan \\ Department of Plant and Environmental Sciences, New Mexico State University, Las Cruces, NM 88003; and Sustainable Agriculture Science Center at Alcalde, New Mexico State University, Alcalde, NM 87511}

\section{Govinda Sapkota}

Department of Plant and Environmental Sciences, New Mexico State University, Las Cruces, NM 88003

Additional index words. fruit drying quality, fruit traits, yield, Ziziphus jujuba, zoning

\begin{abstract}
Jujube cultivars have been imported into the United States for more than 100 years, but cultivar trials have been limited. To accurately recommend cultivars for each region, trials have to be conducted. We have set up jujube cultivar trials at the New Mexico State University (NMSU) Alcalde (2015, USDA hardiness zone 6a), Los Lunas $(2015,7 a)$, and Leyendecker $(2017,8 a)$ Centers with over 35 cultivars at each site with two replicates and a complete random block design. We reported the early performance of fresh-eating cultivars in 2019. Here we report the performance of 19 drying and multipurpose jujube cultivars. Between $40 \%$ and $100 \%$ of jujube trees produced a few fruit to more than $\mathbf{1 0 0}$ fruit in the planting year, depending on cultivar and location. Trees were more upright at Los Lunas than at Alcalde. 'Kongfucui' (KFC) was the most productive cultivar at Alcalde with $13.3 \mathrm{~kg} /$ tree in 2019 , followed by 'Chaoyang', 'Jinkuiwang' (JKW), 'Pitless', and 'Lang'. The yield at Los Lunas was lower than Alcalde for the first 3 years after planting; however, 'Jinsi 2', 'Jinsi 4', 'Jixin', 'Sherwood', 'Sihong', and 'Xiangzao' produced higher yields at Los Lunas than Alcalde in 2019. All cultivars produced higher yields and contained higher soluble solids at Leyendecker than Alcalde and Los Lunas at similar ages. ' $J K W$ ' was the most vigorous and productive cultivar at Leyendecker. 'JKW', 'Xiangzao', and 'Lang' produced more than $3.0 \mathrm{~kg} /$ tree in their second year after planting. ' $\mathrm{JKW}$ ' yielded $12.3 \mathrm{~kg} /$ tree in its third year after planting. Among the three locations, drying cultivars are not recommended for commercial production at Alcalde. However, home gardeners can plant multipurpose and early-drying cultivars at Alcalde. Leyendecker produced the best dry fruit with larger fruit size, rich color, and meaty fruit; dry fruit quality was acceptable in most years at Los Lunas except 2019. We preliminarily recommend some drying and multipurpose cultivars for each location. As trees mature and produce more fruit, we will fine-tune the cultivar recommendations. We also discuss the jujube cultivar zoning information in New Mexico and fruit uses.
\end{abstract}

Jujube (Ziziphus jujuba Mill.) belongs to Rhamnaceae (buckthorn family). Its cultivars were first imported into the United States by Frank N. Meyer from 1908 to 1918 (Meyer, 1916; Yao, 2013). Jujube is a deciduous fruit tree with more than 800 cultivars in China (Liu and Wang, 2009). A good estimate for jujube cultivars in the United States would be $\approx 100$, most casually named and unclassified, often growing in people's backyards. Commercially, 'Li', 'Lang', 'Sugarcane', 'GA866', 'Sherwood', and 'Honeyjar' are common, with 'Li' and 'Lang' being domi- nant, especially 'Li'. 'Li' has round, large fruit and is precocious and productive. Its fruit eating quality is good, but it is not suitable for drying in most areas (Yao et al., 2019).

Jujube fruit size ranges from thumb to golf ball size depending on cultivar. Firsttime tasters usually compare the flavor of jujube to sweet apple or sweet pear. The dry jujube fruit tastes similar to a dry palm date. Dry jujube fruit and seeds from wild jujubes (Z. spinosa $\mathrm{Hu}$ ) are popular traditional medicinal herbs in China. Approximately 60\% of traditional Chinese medicinal prescriptions have dry jujube fruit in them, for its own medicinal value and for minimizing the toxicity of other herbs (Liu, 2008).

For people who have not tasted jujube fruit, the firm texture and sweet flavor of fresh fruit would be easier to accept than dry fruit. With cold storage technology, some cultivars can be stored for 2 months or longer depending on cultivar and maturation stage at picking (Chen et al., 2008; Li and Wen, 2008; Wang et al., 2008). Fresh jujube fruit have a high ascorbic acid (vitamin C) content, but $90 \%$ or more of it is lost during the sun drying process (Huang et al., 2017; Yao, 2013). Dry fruit have the advantage of multiple uses and easy storage. They can be stored for 1 year or more at room temperature or 2 to 3 years in cold storage, greatly extending the market season. Dry jujube fruit can be processed further as fruit slices/rings, wine, vinegar, drinks, or ingredients in cooking/baking or used for healthy component extraction or other value-added products (Guo and Shan, 2010). As jujube acreage increases, combined with the relatively short marketing period for fresh jujubes, drying or multipurpose cultivars (good for both fresh eating and drying) can provide more marketing choices for growers. Consumers also demand yearround jujube fruit supplies for different end uses.

'Lang' is known as a drying cultivar, but there is no study or publication on drying cultivars in the United States, except for a few sentences from a publication from the 1920s (Thomas, 1927). With this in mind, we included drying cultivars and multipurpose cultivars in our trials at three NMSU study sites: Alcalde (2015), Los Lunas (2015), and Leyendecker (2017) (Yao and Heyduck, 2018; Yao et al., 2019). We previously reported the early performance of fresh-eating and ornamental cultivars. Here, we evaluate the performance of drying and multipurpose cultivars.

\section{Material and Methods}

Source of cultivars. Among the 19 cultivars tested (Table 1), six were originally from a nursery in California and 13 were imported as scionwood directly from China in 2011; these are in addition to the previously reported fresh-eating and ornamental cultivars (Yao, 2018; Yao et al., 2015, 2019). Those imported cultivars were grafted onto sour jujube rootstocks and quarantined for 2 years with inspections from the U.S. Department of Agriculture (USDA) Animal and Plant Health Inspection Service (Yao et al., 2019). On the basis of preliminary observation after collection or importation, we began propagating them at Alcalde for cultivar trials.

Cultivar trials. Two jujube cultivar trials with more than 35 cultivars per site were planted at the NMSU Los Lunas and Alcalde Centers in Apr. 2015 in completely randomized block designs. There were two replicates (blocks) and two trees per cultivar in each 
Table 1. Cultivars trialed at New Mexico State University Alcalde, Los Lunas, and Leyendecker Centers in New Mexico.

\begin{tabular}{|c|c|c|c|c|}
\hline Cultivar & Source & Alcalde & Los Lunas & Leyendecker \\
\hline Chaoyang & China & $\mathrm{X}$ & $\mathrm{X}$ & \\
\hline Don Polenski & California & $\mathrm{X}$ & $\mathrm{X}$ & \\
\hline Jinkuiwang (JKW) & China & $\mathrm{X}$ & $\mathrm{X}$ & $\mathrm{X}$ \\
\hline Jinsi 2 & China & $\mathrm{X}$ & $\mathrm{X}$ & $\mathrm{X}$ \\
\hline Jinsi 3 & China & $\mathrm{X}$ & $\mathrm{X}$ & $\mathrm{X}$ \\
\hline Jinsi 4 & China & $\mathrm{X}$ & $\mathrm{X}$ & \\
\hline Jixinzao & China & $\mathrm{X}$ & $\mathrm{X}$ & $\mathrm{X}$ \\
\hline Junzao & China & $\mathrm{X}$ & $\mathrm{X}$ & $\mathrm{X}$ \\
\hline Kongfucui (KFC) & China & $\mathrm{X}$ & $\mathrm{X}$ & $\mathrm{X}$ \\
\hline Lang & California & $\mathrm{X}$ & $\mathrm{X}$ & $\mathrm{X}$ \\
\hline Pitless & China & $\mathrm{X}$ & $\mathrm{X}$ & $\mathrm{X}$ \\
\hline Sherwood & California & $\mathrm{X}$ & $\mathrm{X}$ & $\mathrm{X}$ \\
\hline Sihong & California & $\mathrm{X}$ & $\mathrm{X}$ & $\mathrm{X}$ \\
\hline Xiangzao & China & $\mathrm{X}$ & $\mathrm{X}$ & $\mathrm{X}$ \\
\hline Xingguang & China & $\mathrm{X}$ & $\mathrm{X}$ & $\mathrm{X}$ \\
\hline Banzao $^{z}$ & China & $\mathrm{X}$ & $\mathrm{X}$ & $\mathrm{X}$ \\
\hline Globe & California & $\mathrm{X}$ & $\mathrm{X}$ & $\mathrm{X}$ \\
\hline Huizao & China & & & $\mathrm{X}$ \\
\hline Shuimen & California & $\mathrm{X}$ & $\mathrm{X}$ & $\mathrm{X}$ \\
\hline
\end{tabular}

${ }^{\mathrm{z}}$ Cultivars below the double line in the table are for observation only since there were not enough plants for full replications.

block at each site. Those trees were grafted in Spring 2014 and grew in the field for one season, reaching 1.0 to $1.2 \mathrm{~m}$ in height. The planting density was $2.44 \times 3.66 \mathrm{~m}$ at Alcalde and $3.05 \times 4.57 \mathrm{~m}$ at Los Lunas. In Apr. 2017, another cultivar trial was planted at the NMSU Leyendecker Center with $3.05 \times 4.57 \mathrm{~m}$ planting density (Yao and Heyduck, 2018). Plants for Leyendecker site were grafted at Alcalde in spring 2016, similar quality as plants for Alcalde and Los Lunas. Here we report the performance of the drying and multipurpose cultivars (Table 1). Location and elevation for each site are as follows: Alcalde Center: lat. $36^{\circ} 05^{\prime} 27.94^{\prime \prime} \mathrm{N}$, long. $106^{\circ} 03^{\prime} 24.56^{\prime \prime} \mathrm{W}$, elevation $1730 \mathrm{~m}$; Los Lunas Center: lat. $34^{\circ} 46^{\prime} 04.7^{\prime \prime} \mathrm{N}$, long. $106^{\circ} 45^{\prime} 45.7^{\prime \prime} \mathrm{W}$, elevation $1478 \mathrm{~m}$; Leyendecker Center: lat. $32^{\circ} 12^{\prime} 08.9^{\prime \prime} \mathrm{N}$, long. $106^{\circ} 44^{\prime} 41.4^{\prime \prime} \mathrm{W}$, elevation $1176 \mathrm{~m}$ (Yao et al., 2019). Figure 1 shows the historic weather data for these

Received for publication 4 Aug. 2020. Accepted for publication 1 Sept. 2020.

Published online 6 October 2020.

We thank Dr. Richard Heerema and Frank Sholedice from New Mexico State University for their critical review of this manuscript before submission. We acknowledge the technical assistance of David Archuleta and David Salazar at the Alcalde Center; Mark Marsalis, Gill Giese, Tom Place, Dennis Price, Charles Havlik, and Jose Gonzalez at the Los Lunas Center; and Dave Lowry, Orlando Moralez, Ralph Trevino, and Rolando Gonzalez at the Leyendecker Center. This project was partially supported by the Specialty Crop Block Grant through the New Mexico Department of Agriculture, Hatch funds from the U.S. Department of Agriculture National Institute of Food and Agriculture, and the New Mexico State University Agricultural Experiment Station.

S.Y. is the corresponding author. E-mail: yaos@ nmsu.edu.

This is an open access article distributed under the CC BY-NC-ND license (https://creativecommons. org/licenses/by-nc-nd/4.0/). three sites (Western Regional Climate Center, 2020). With limited weather data for the Leyendecker site, we used Las Cruces data to represent Leyendecker, which is $12 \mathrm{~km}$ away. The historic average precipitation and average annual temperature for Alcalde, Las Cruces, and Los Lunas were 251, 234, and $231 \mathrm{~mm}$, and $10.6,16.5$, and $13.0^{\circ} \mathrm{C}$, respectively.

Field management. As described in Yao et al. (2019), no specific training system was used for these cultivar trials. We pruned the trees annually in February/March to stimulate side branches if there were not enough scaffold branches in the first 1 to 3 years after planting. For cultivars with excessive branches, we pruned out competitive and crowded branches to avoid overshading. In the third year and later after planting, we topped off the central leaders and main branches to slow down the apical growth with one cut (Yao, 2019). For the Alcalde location, since year 3 after planting, trees were sprayed with water three or four times during full bloom period at 3- to 4-d intervals at 6:00 to 7:00 PM.

Flood irrigation was used at all three sites, once every 7 to $10 \mathrm{~d}$ at Alcalde (sandy loam soil) and once every 2 to 3 weeks at the Los Lunas and Leyendecker Centers (loam/clay soils) if there was no natural precipitation. Trees were fertilized once per year at a rate of 45 to $50 \mathrm{~kg} \cdot \mathrm{ha}^{-1} \mathrm{~N}, 20$ to $30 \mathrm{~kg} \cdot \mathrm{ha}^{-1} \mathrm{P}$, and 25 to $30 \mathrm{~kg} \cdot \mathrm{ha}^{-1} \mathrm{~K}$ in May to early June. Fertilizer and rates varied slightly from site to site due to fertilizer availability (Yao et al., 2019).

Tree measurement, yield, and fruit data collection. In the planting year, fruit numbers per tree were counted at each site (2015 for Alcalde and Los Lunas, and 2017 for Leyendecker). In year 2 and after, each tree's yield was manually harvested, and weights of total yield and 30 fruit (if available) were recorded. Depending on maturation season, two to four harvests were conducted each year per site. At the beginning, we tried two harvests per tree for some cultivars. With limited labor support in later years, however, we did one harvest per cultivar when most fruit were close to full red stage. Fruiting pictures were taken each year. Fruit were juiced with a garlic press, and soluble solids content was measured with a digital refractometer (Atago PAL-1 digital pocket refractometer; Bellevue, WA) from a composite sample of eight to 10 fruit per cultivar. Fully red or close to fully red fruit were picked for soluble solids measurement. Fruit diameters and lengths $(n=30)$ were measured with a digital caliper for fruit from Alcalde and Los Lunas in 2017.

Tree crown heights and widths were measured 3 years after planting (Mar. 2018 for Los Lunas and Alcalde, and Mar. 2020 for Leyendecker). Tree growing habits were classified as four types: upright, more upright than bushy, more bushy than upright, and bushy. Branch numbers directly from the central leader (trunk) were counted for each tree even though the length and diameter varied depending on cultivar.

Drying study. The preliminary drying studies were conducted using either sundrying or oven-drying at Alcalde Center with fruit from all study sites. Drying racks $(5 \times 10$ $\mathrm{cm}$ beam on sides, wire screen with $1.3-\mathrm{cm}$ opening on the bottom) were used for sundrying, and oven-drying was conducted at temperatures of 50 to $60{ }^{\circ} \mathrm{C}$ with fruit on perforated aluminum pans. We also testtrialed sun-drying of drying and multipurpose cultivars in 2014 and 2015 at Alcalde; those trees were discussed in previous studies (Yao, 2018).

For multipurpose cultivars, no formal fresh-eating quality evaluation was carried out. Fruit quality was based on the corresponding author's fruit tasting during the past 10 years plus the responses of customers at our annual jujube fruit tasting workshop in late September each year. Drying fruit quality was preliminarily evaluated by their appearance, flesh texture, flesh thickness (meaty or skinny), and limited cooking uses. Formal evaluation will be conducted later as more samples are available.

Cultivar thorn rating was conducted in Mar. 2019 at Alcalde based on the straight thorn length on branches of different ages. Analyses of variance were conducted for yield and tree growth (height, width, growing habit, and number of branches) with Statistix 10 (Analytical Software, Tallahassee, FL).

\section{Results}

Precocity. Jujube trees were more precocious than most common deciduous fruit species. Drying and multipurpose cultivars fruited more at Alcalde than at Los Lunas in the planting year. The fruiting tree percentages and average fruit number/tree were $77 \%$ and $42 \%$, and 14.4 and 3.8 fruit/tree at Alcalde and Los Lunas, respectively. At Leyendecker, $100 \%$ of trees bore fruit in the planting year, with average of 29 fruit/tree. In the planting year, cultivar JKW had 140 fruit/ 
tree. Tree growth and production varied by cultivar, location, and cultural management.

Tree growth and growing habits. Tree heights at Los Lunas and Alcalde were similar after 3 years in the field (Table 2), but Alcalde trees spread wider than those at Los Lunas, and the relatively heavy, early crops at Alcalde may have contributed to that. In years 4 and 5, trees were taller and stronger at Los Lunas than at Alcalde (data not shown). Cultivars Jinsi 2 and Jinsi 4 had small trees with weak and thin branches. 'Sihong' had the strongest plants at both
Alcalde and Los Lunas, with tall, vigorous, and bushy trees (Table 2). 'JKW' had the largest trees at Leyendecker among all cultivars tested (fresh-eating, drying, and multipurpose cultivars). 'Huizao' had the smallest trees among those cultivars listed (Table 2). 'Huizao' was slightly taller with fewer branches than 'Dragon' (data not shown).

In terms of tree growing habits, trees were more upright at Los Lunas than at Alcalde and Leyendecker (Table 2). Trees at Alcalde were less upright and with more branches, which could be the result of a combination of

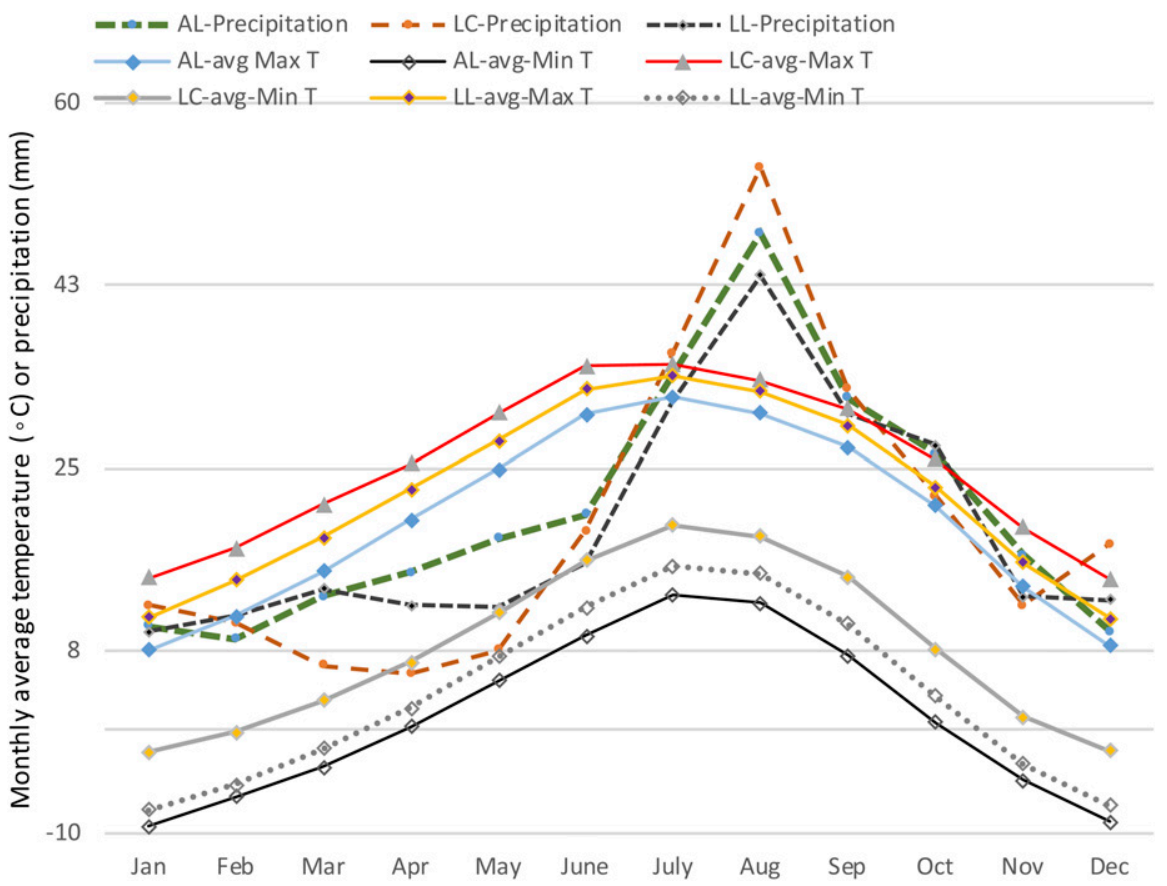

Fig. 1. Historic weather data (monthly average max and min temperatures and precipitation) for Alcalde (AL, 1953-2005), Las Cruces (LC, 1959-2005), and Los Lunas (LL, 1923-2005).

early crop loads, weather, soil types, and cultural management, especially irrigation intervals. 'Sherwood' was the most upright cultivar at Los Lunas, whereas 'JKW' was the bushiest type at Leyendecker among cultivars tested (Table 2). For Los Lunas, this could be from a combination of irregular irrigation in early spring, relatively low yields in early years, and fertile soil, which stimulated lots of upright new growth. Trees at Leyendecker were taller, with longer new shoot growth than at Los Lunas and Alcalde at equivalent age. With good fruit set on the current year's new growth, the crop load leveled the branches. Tree uprightness depends on cultivar, crop load, cultural management, pruning, and fertilizer rate.

Yields. At Alcalde, 'KFC' was the most productive cultivar among all cultivars tested, followed by 'Chaoyang', 'JKW', 'Pitless', and 'Lang', whereas 'Jixin', 'Sherwood', and 'Jinsi 4' were the least productive (Table 3, Fig. 2). At Los Lunas, the average yield for the third year (2017) was lower than at Alcalde, but yields were catching up in years 4 and 5 . Due to severe raccoon damage to trees in Los Lunas, it was difficult to estimate the true yield in 2019; however, from the fruit harvested, yields of 'Jinsi 2', 'Jinsi 4', 'Jixin', 'Sherwood', 'Sihong', 'Xiangzao', and 'Xingguang' were higher than those at Alcalde. Cultivar Chaoyang was at the corner of the field, which was badly damaged by raccoons. 'Chaoyang' trees always had heavy crop load each year at both Alcalde and Los Lunas during yield evaluation in late August each year.

Trees at Leyendecker produced higher yields than trees at Alcalde and Los Lunas at equivalent age (Table 2, Fig. 2). Also, the late cultivars Jixin, JKW, Sherwood, and

Table 2. Tree growth of drying and multipurpose cultivars at Alcalde (AL) and Los Lunas (LL) in Mar. 2018 and Leyendecker (LK) in Mar. 2020.

\begin{tabular}{|c|c|c|c|c|c|c|c|c|c|c|c|c|c|}
\hline \multirow[b]{2}{*}{ Cultivar } & \multicolumn{2}{|c|}{ Tree ht $(\mathrm{cm})$} & \multicolumn{2}{|c|}{ Tree width $(\mathrm{cm})$} & \multicolumn{2}{|c|}{ Uprightness } & \multicolumn{2}{|c|}{ Branches } & \multirow[b]{2}{*}{ Cultivar } & \multirow{2}{*}{$\frac{\mathrm{Ht}(\mathrm{cm})}{\mathrm{LK}}$} & \multirow{2}{*}{$\frac{\text { Width }(\mathrm{cm})}{\mathrm{LK}}$} & \multirow{2}{*}{$\frac{\text { Uprightness }}{\text { LK }}$} & \multirow{2}{*}{$\frac{\text { Branches }}{\text { LK }}$} \\
\hline & $\mathrm{AL}$ & LL & $\mathrm{AL}$ & $\mathrm{LL}$ & $\mathrm{AL}$ & $\mathrm{LL}$ & $\overline{\mathrm{AL}}$ & $\overline{\mathrm{LL}}$ & & & & & \\
\hline Chaoyang & 290 & 296 & 194 & 131 & 3.0 & 1.8 & 5.0 & 2.7 & Banzao & $298{b c^{z}}^{2}$ & $198 \mathrm{bc}$ & $3.0 \mathrm{ab}$ & $8.8 \mathrm{bc}$ \\
\hline Don Polenski & 255 & 283 & 189 & 123 & 3.3 & 2.0 & 5.5 & 3.0 & Jinsi 2 & $284 \mathrm{bc}$ & $161 \mathrm{c}$ & $3.0 \mathrm{ab}$ & $7.1 \mathrm{bcd}$ \\
\hline JKW & 284 & 315 & 180 & 205 & 3.8 & 2.8 & 8.0 & 4.8 & Jinsi 3 & $301 \mathrm{abc}$ & $184 \mathrm{bc}$ & $3.0 \mathrm{ab}$ & $7.3 \mathrm{bcd}$ \\
\hline Jinsi 2 & 231 & 271 & 168 & 134 & 3.0 & 2.5 & 4.7 & 3.0 & Jixin & $334 \mathrm{ab}$ & $196 \mathrm{bc}$ & $2.4 \mathrm{~cd}$ & $5.3 \mathrm{~cd}$ \\
\hline Jinsi 3 & 263 & 303 & 226 & 168 & 4.0 & 3.0 & 8.0 & 6.0 & JKW & $361 \mathrm{a}$ & $255 \mathrm{a}$ & $3.3 \mathrm{a}$ & $12.5 \mathrm{a}$ \\
\hline Jinsi 4 & 238 & 170 & 150 & 104 & 3.3 & 3.0 & 3.5 & 3.5 & $\mathrm{KFC}$ & $270 \mathrm{c}$ & $180 \mathrm{bc}$ & $2.8 \mathrm{abc}$ & $4.5 \mathrm{~d}$ \\
\hline Jixin & 326 & 308 & 219 & 140 & 3.0 & 2.0 & 4.5 & 3.8 & Lang & $301 \mathrm{bc}$ & $184 \mathrm{bc}$ & $2.8 \mathrm{bc}$ & $8.3 \mathrm{bcd}$ \\
\hline Junzao & 245 & 253 & 185 & 105 & 3.3 & 2.0 & 5.3 & 2.8 & Sherwood & $322 \mathrm{abc}$ & $195 \mathrm{bc}$ & $2.2 \mathrm{~d}$ & $9.5 \mathrm{ab}$ \\
\hline $\mathrm{KFC}$ & 339 & 308 & 245 & 155 & 3.3 & 2.3 & 5.3 & 4.5 & Sihong & $336 \mathrm{ab}$ & $202 \mathrm{bc}$ & $2.2 \mathrm{~d}$ & $4.5 \mathrm{~d}$ \\
\hline Lang & 301 & 273 & 226 & 170 & 3.3 & 2.3 & 8.3 & 4.8 & Xiangzao & $299 \mathrm{bc}$ & $215 a b$ & $2.5 \mathrm{~cd}$ & $10.8 \mathrm{ab}$ \\
\hline Pitless & 231 & 328 & 209 & 175 & 4.0 & 2.5 & 7.5 & 4.3 & Xingguang & $279 \mathrm{c}$ & $161 \mathrm{c}$ & $3.0 \mathrm{ab}$ & $8.3 \mathrm{bcd}$ \\
\hline Sherwood & 373 & 367 & 208 & 125 & 3.0 & 1.1 & 7.5 & 2.0 & Avg & 306 & 197 & 2.8 & 8.0 \\
\hline Sihong & 313 & 343 & 219 & 221 & 3.3 & 2.8 & 4.8 & 6.0 & Globe $^{y}$ & 328 & 196 & 2.5 & 8.5 \\
\hline Xiangzao & 313 & 299 & 200 & 166 & 3.0 & 2.3 & 6.0 & 3.8 & Huizai & 193 & 73 & 2.2 & 2.0 \\
\hline Xingguang & 259 & 301 & 175 & 151 & 3.3 & 2.0 & 6.5 & 4.5 & Junzao & 283 & 175 & 2.5 & 5.5 \\
\hline Avg & 283 & 294 & 200 & 152 & 3.3 & 2.3 & 6.0 & 3.9 & Pitless & 290 & 183 & 2.8 & 5.0 \\
\hline Cultivar & & & & & & & & & Shuimen & 314 & 191 & 3.3 & 11.5 \\
\hline Location & & & & & & & & & & & & & \\
\hline Cultivar $\times$ location & & & & & & & & & & & & & \\
\hline Banzao $^{y}$ & 295 & 288 & 173 & 160 & 2.5 & 2.5 & 6.0 & 5.5 & & & & & \\
\hline Globe & 332 & 298 & 148 & 158 & 2.5 & 2.0 & 5.0 & 5.5 & & & & & \\
\hline Shuimen & 327 & 320 & 201 & 203 & 3.5 & 3.0 & 10.0 & 4.5 & & & & & \\
\hline
\end{tabular}

${ }^{\mathrm{z}}$ Any two means within a column not followed by the same letter are significantly different at $P \leq 0.05$ with Fisher's protected least significant difference procedure.

${ }^{\mathrm{y}}$ Cultivars below the double line did not have full replications and are presented for reference only.

Ns, $*, * *$ Nonsignificant or significant at $P \leq 0.05$ or 0.01 , respectively. 
Table 3. Jujube cultivar yields (g) from 2017 to 2019 at Alcalde (AL) and Los Lunas (LL) and Leyendecker (LK) from 2018 to 2019.

\begin{tabular}{|c|c|c|c|c|c|c|c|c|c|c|}
\hline$\overline{\text { Cultivar }}$ & AL16 & AL17 & AL18 & AL19z & LL16 & LL17 & LL18 & LL19 & LK18 & $\overline{\text { LK19 }}$ \\
\hline Chaoyang & 1,509 & $6,829 \mathrm{~b}^{\mathrm{y}}$ & $9,297 \mathrm{~b}$ & $13,402 \mathrm{a}$ & 710 & $2,243 a b c$ & $6,209 \mathrm{bcd}$ & $2,544 \mathrm{e}$ & & \\
\hline Don Polenski & 288 & $2,618 \mathrm{de}$ & $2,311 \mathrm{e}$ & 5,789 cde & 146 & $726 \mathrm{~d}$ & 2,858 ef & $1,730 \mathrm{e}$ & & \\
\hline Jinkuiwang & 132 & $1,543 \mathrm{ef}$ & $6,271 \mathrm{~cd}$ & $9,324 \mathrm{~b}$ & 0 & 1,802 abcd & $1,314 \mathrm{f}$ & $8,505 \mathrm{abc}$ & 4,712 & 12,313 \\
\hline Jinsi 2 & 86 & $2,033 \mathrm{ef}$ & $1,980 \mathrm{e}$ & $4,731 \mathrm{def}$ & 92 & $1,104 \mathrm{~cd}$ & $2,582 \mathrm{ef}$ & $8,373 \mathrm{abc}$ & 998 & 3,687 \\
\hline Jinsi 3 & 27 & 1,918 ef & $6,562 \mathrm{bc}$ & $9,048 \mathrm{bc}$ & 7 & $818 \mathrm{~cd}$ & $3,432 \mathrm{def}$ & 5,871 bcde & 1,252 & 5,940 \\
\hline Jinsi 4 & 429 & 3,330 cde & $971 \mathrm{e}$ & 2,615 ef & 448 & $1,385 \mathrm{bcd}$ & $1,018 \mathrm{f}$ & 7,568 abcd & & \\
\hline Jixin & 47 & $445 \mathrm{f}$ & $1,067 \mathrm{e}$ & $2,243 \mathrm{f}$ & 146 & $437 d$ & $1,314 \mathrm{f}$ & 3,268 de & 1,598 & 5,229 \\
\hline Junzao & 201 & $2,620 \mathrm{de}$ & $1,274 \mathrm{e}$ & 4,447 ef & 380 & $1,101 \mathrm{~cd}$ & 3,869 cdef & 3,959 cde & 659 & 2,078 \\
\hline Kongfucui & 383 & $11,572 \mathrm{a}$ & $13,686 \mathrm{a}$ & $13,364 \mathrm{a}$ & 339 & $2,696 \mathrm{ab}$ & $9,791 \mathrm{a}$ & $10,692 \mathrm{a}$ & 2,435 & 5,549 \\
\hline Lang & 316 & $5,369 \mathrm{bc}$ & $3,450 \mathrm{de}$ & $8,321 \mathrm{bcd}$ & 639 & $2,560 \mathrm{ab}$ & 5,254 cde & $7,878 \mathrm{abcd}$ & 3,432 & $-x$ \\
\hline Pitless & 625 & $4,877 \mathrm{bc}$ & $6,825 \mathrm{bc}$ & $9,624 \mathrm{~b}$ & 604 & 1,871 abcd & $6,720 \mathrm{abc}$ & 6,521 abcde & 2,285 & 5,962 \\
\hline Sherwood & 204 & $2,290 \mathrm{def}$ & $2,178 \mathrm{e}$ & $2,221 \mathrm{f}$ & 745 & $701 \mathrm{~d}$ & 3,652 cdef & 5,033 bcde & 1,684 & - \\
\hline Sihong & 169 & 3,514 cde & $1,804 \mathrm{e}$ & 4,386 ef & 133 & $3,081 \mathrm{a}$ & $3,045 \mathrm{def}$ & $9,135 \mathrm{ab}$ & 2,321 & 2,174 \\
\hline Xiangzao & 143 & $4,276 \mathrm{~cd}$ & $3,322 \mathrm{e}$ & $5,416 \mathrm{def}$ & 777 & $2,723 \mathrm{ab}$ & $8,954 \mathrm{ab}$ & $8,671 \mathrm{abc}$ & 3,349 & 9,941 \\
\hline Xingguang & 103 & $2,568 \mathrm{de}$ & $1,485 \mathrm{e}$ & 3,926 ef & 448 & 1,829 abcd & 4,112 cdef & $7,666 \mathrm{abcd}$ & 2,123 & 5,051 \\
\hline Avg & 310 & 3,720 & 4,166 & 6,590 & 374 & 1,672 & 4,275 & 6,494 & 2,054 & 5,257 \\
\hline Banzao & 40 & 674 & 2,369 & 6,393 & 105 & 637 & 3,164 & 5,816 & 664 & 996 \\
\hline Globe & 60 & 1,787 & 810 & & 141 & 807 & 2,258 & & 1,848 & 2,764 \\
\hline Huizao & & & & & & & & & 700 & 983 \\
\hline Shuimen & 122 & 3,560 & 4,659 & 6,561 & 310 & 1,513 & 3,814 & 13,920 & 488 & 1,992 \\
\hline
\end{tabular}

${ }^{\mathrm{z}}$ Most cultivars did not fully mature at Alcalde, and the frost on 8 Oct. 2019 ended the season at Alcalde and Los Lunas.

${ }^{y}$ Any two means within a column not followed by the same letter are significantly different at $P \leq 0.05$ with Fisher's protected least significant difference procedure.

${ }^{\mathrm{x}}$ Cultivars were used for nutrient dynamic sampling in another study in 2019.

Xiangzao performed better at Leyendecker (southernmost site) than at the northern (Alcalde) or central (Los Lunas) sites. 'Jinsi' series also fruited more heavily at Leyendecker at equivalent age than at Alcalde and Los Lunas (Table 2, Fig. 2). 'JKW' at Leyendecker was the most vigorous and productive among those cultivars tested at Leyendecker. 'JKW', 'Xiangzao', and 'Lang' produced more than $3.0 \mathrm{~kg} /$ tree in their second year after planting. Even with severe bird damage, 'JKW' and 'Xiangzao' yielded 12.3 and $9.9 \mathrm{~kg} / \mathrm{tree}$, respectively, in the third year after planting in 2019 at Leyendecker (Table 3). 'Jinsi 3' and 'Jixin' also did well in year 3, with higher yields than those cultivars at equivalent age at Alcalde and Los Lunas. 'KFC' and 'Pitless' yielded high from Alcalde to Los Lunas to Leyendecker.

Due to cold weather from mid-May to early June 2019 and the relatively early frost in late September/early October, late cultivars did not fully mature at both Alcalde and Los Lunas, and Alcalde had more cultivars (mid and late cultivars) affected than Los Lunas (mid-late and late cultivars). Fruit set and maturation at Leyendecker were unaffected.

'Sihong' had the most vigorous and biggest canopy at Los Lunas and Alcalde, but the early season fruit sets were limited, with most fruit occurring in the current year's new growth without cultural practice interventions like girdling or gibberellin application. By year 5, 'Sihong' fruit yield at Los Lunas, but not at Alcalde, was increasing.

'Jinsi 2' and 'Jinsi 4' had smaller plants with low yield in early years, and 'Jinsi 4' had very sweet and small fruit at Alcalde, which is why 'Jinsi 4' was not included at Leyendecker. 'Pitless' also had small trees (similar to 'Jinsi 2' and 'Jinsi 4'), very small fruit with excellent drying quality, and higher crop yields in early years than 'Jinsi 2' and 'Jinsi
4'. However, 'Jinsi 2' and 'Jinsi 4' were catching up in 2019, especially at Los Lunas. 'Jinsi 3 ' and 'JKW' had larger trees than 'Jinsi 2', 'Jinsi 4', and 'Pitless', even though they are all 'Jinsi' series cultivars.

Fruit quality. There were sampling variations because not every cultivar was sampled at the premium time, but the general trends were clear. For any given cultivar, fruit size, average fruit weight, and soluble solids content were higher in southern locations, Leyendecker $>$ Los Lunas $>$ Alcalde (Table 4). The significant fruit quality difference between Alcalde and Leyendecker was partially due to the short growing season in 2019 at Alcalde, which was the shortest from 2010 to 2019 (New Mexico Climate Center, 2020). 'Pitless' reached soluble solids content greater than $40 \%$. 'KFC', 'Sihong', 'Jinsi 2', 'Jinsi 3', and 'Sherwood' were good for both fresh eating and drying. 'Lang', 'Don Polenski', 'Junzao', and 'Xingguang' were acceptable for fresh eating but better for drying. 'KFC' had the best fresh-eating texture among multipurpose cultivars. 'Xiangzao' and 'Globe' were drying-only cultivars; they had a woody texture when fresh, not suitable for fresh eating. For cultivar pictures and general descriptions, please visit https:// aces.nmsu.edu/jujube/.

For fruit sizes, large-sized cultivars $(>15$ g) (Table 4) were Globe, Xiangzao, Sherwood, Lang/Don Polenski, Xingguang, JKW and Jinsi 3; medium-sized (10-15 g) cultivars were JKW, KFC, Shuimen, Jinsi 3, Jixin, and Jinsi 2; and, small-sized cultivars $(<10 \mathrm{~g})$ were Pitless, Jinsi 4, and Chaoyang. 'JKW' and 'Jinsi 3' can be included in the large or medium group depending on location and year. 'Shuimen' could be in the large-sized group at Leyendecker site.

For maturation season, 'Banzao', 'Shuimen', and 'Pitless' are relatively early cultivars; 'Lang', 'Xingguang', 'Huizao', 'Junzao', 'Jinsi 2', and 'KFC' are midseason; and 'Jixin', 'Jinsi 3', 'Globe', 'JKW', 'Xiangzao', and 'Sherwood' are mid to late season.

Drying fruit quality. Jujube fruit drying quality was affected by cultivar, climate conditions, cultural management, and length of growing season. Leyendecker had the best drying quality among the three locations, with larger and meatier fruit with rich color (Fig. 3, row 3 vs. rows 1 and 2). Alcalde had the worst drying fruit quality. At Alcalde, the drying quality could be reasonable in some years, as in 2014 and 2015 with $150 \mathrm{~d}$ and $167 \mathrm{~d}$ of growing season, respectively (Fig. 3, rows 1 and 2). In 2014, 'KFC', 'Jinsi 2', 'Jixin', 'Pitless', 'Shuimen', and 'Lang' all dried well, with meaty fruit and rich color, but 'Globe', 'JKW', 'Sihong', and 'Xiangzao' had yellowish fruit color (Fig. 3) and had not fully matured, although 'Sihong' still had meaty fruit. In 2019 with 123 d of growing season (shortest growing season in the previous 10 years), most cultivars were forced to mature or were frozen on the trees. Fruit did not dry well, with skinny fruit and yellowish color. Late cultivar Sherwood never fully matured at Alcalde, whereas Sherwood fully matured at Los Lunas in all years except 2019. In a short growing season year like 2019, even 'Jinsi 2', 'Jinsi 3', 'JKW', and 'Jixin' together with 'Sherwood' did not fully mature before the first freeze in 2019 at Los Lunas, whereas trees at Leyendecker were unaffected in 2019 since its growing season was still long enough for all cultivars to fully mature.

'Jinsi 4' and 'Pitless' both had high soluble solids content and excellent drying quality, but small fruit; 'Chaoyang' also had small fruit but tart flavor. The fruit of 'Jinsi 4' at Los Lunas were getting larger in 2019. 'Huizao' had excellent dry fruit quality, but its slow growing habits should be considered as a negative trait for commercial production. 'Sihong' is suitable for fresh eating and 

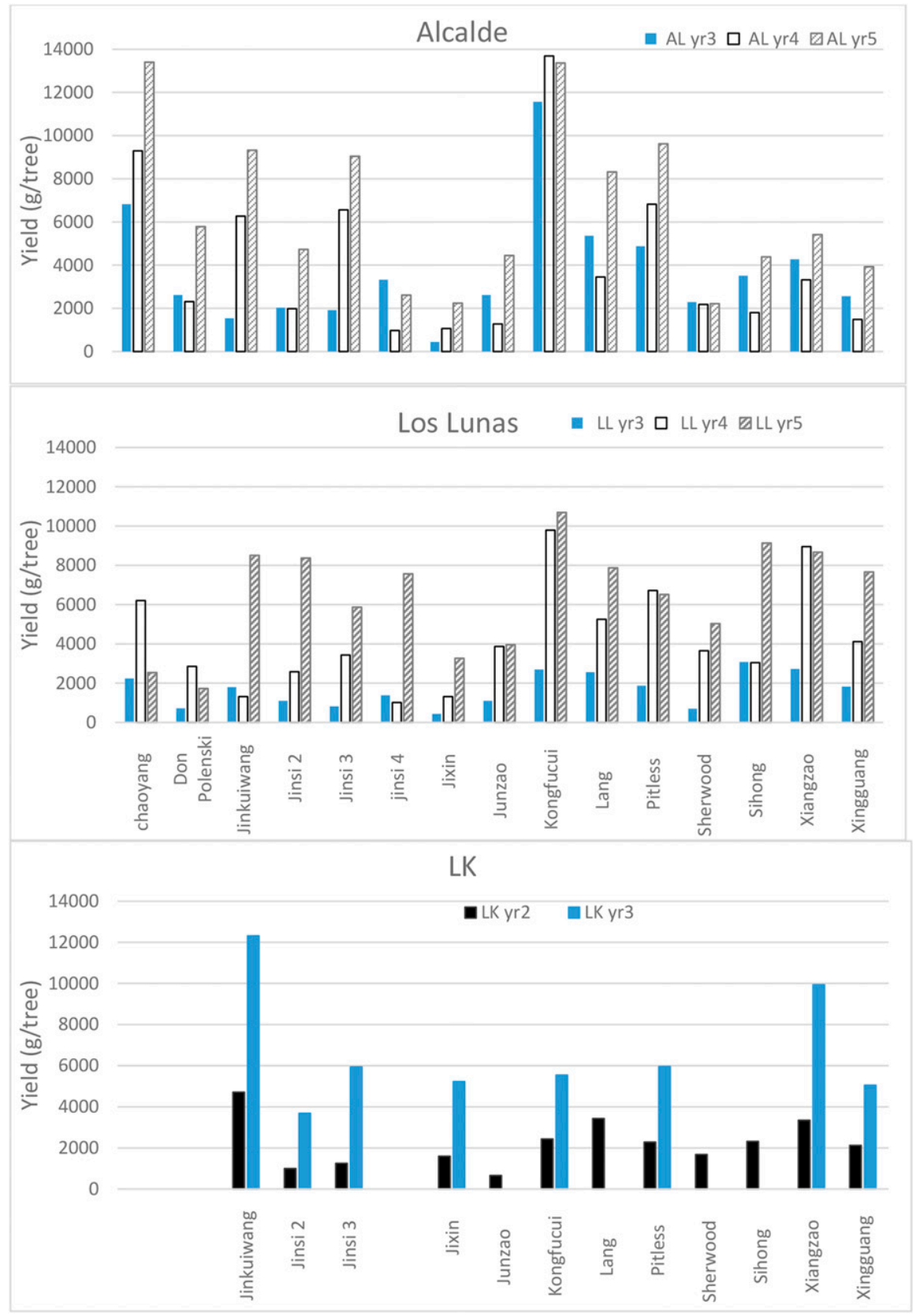

Fig. 2. 2017 jujube cultivar yields from year 3 to year 5 after planting at Alcalde and Los Lunas and from year 2 to year 3 at Leyendecker site.

drying. Its dry fruit is meaty with nice flavor and fine wrinkles on surface.

'Jinsi' series, 'Jixin', 'Sherwood', and 'Sihong' had firm texture and sweet flavor. 'Lang', 'Don Polenski', 'Junzao', and 'Xingguang' had loose texture. Dry fruit quality has several components: appearance, skin color, texture, fruit size/uniformity, and eating, processing, and cooking quality. These are some preliminary results.

Thorniness. Jujube trees become less thorny as they age. Three-year-old branches had longer thorns than those on one-year-old branches. Thorniness also depends on cultivar. Among those cultivars tested, Jinsi 4 and Xiangzao had longer thorns than others. 'Junzao', 'Lang', 'Sherwood', 'Sihong', and 'Shuimen' were almost thornless on 1-year-
Alcalde $\left(10.6{ }^{\circ} \mathrm{C}\right)$, NM (Western Regional Climate Center, 2020). From our experience in the past 10 years, early and midseason cultivars have performed well at Alcalde in most years, but late cultivars have not, especially in extreme years such as 2019. Los Lunas has an average annual temperature of $13.0^{\circ} \mathrm{C}$, and most cultivars from early to late like 'Sherwood' and 'Xiangzao' continue to perform well except for in extreme years like 2019, which had a much shorter growing season than normal. Leyendecker has an average annual temperature of $16.5^{\circ} \mathrm{C}$, and all cultivars produced well in all years. As we collect more cultivar information, a jujube zoning map should be produced in the future. Taos, NM, has an average annual temperature of $8.3^{\circ} \mathrm{C}$, and only some early cultivars can produce well, or in protected areas such as on the south side of a house or near a wall. The USDA Hardiness Zone map can roughly estimate whether jujube trees can survive and grow at a site (USDA, 2012) but cannot estimate their productivity and fruit quality because hardiness zones are based on average minimum winter temperature. USDA Hardiness Zones are more useful to guide jujube planting in the semiarid southwestern United States, which has plenty of sunshine in summer, but not in the northeastern United States with its humid and cool summers.

The average annual temperature is linked to the average frost-free days and length of growing season. Alcalde had an average of $150 \mathrm{~d}$ of frost-free days $\left(0^{\circ} \mathrm{C}\right)$ from 2010 to 2019 and $146 \mathrm{~d}$ from 1953 to 2019, with $167 \mathrm{~d}$ in 2015 and $122 \mathrm{~d}$ in 2019 (New Mexico Climate Center, 2020). With the last frost on 24 May 2019, tree growth, blooming, and fruit set were greatly delayed; fruit maturation was also delayed but the early frost on 23 Sept. was relatively early. The consequence was that most midseason cultivars could not mature, and the fruit quality was greatly reduced. With data from Alcalde, it seems jujube trees require an average of 140 to $150 \mathrm{~d}$ of frost-free days. In China, $\mathrm{Li}$ et al. (2005) reported 170 to $230 \mathrm{~d}$. For sites where there are $130 \mathrm{~d}$ frost-free days or less, no commercial production is recommended. With 140 to $150 \mathrm{~d}$ of frost-free days, commercial production would be mainly for fresh fruit production, with limited cultivar selections of early and midseason. With 180 to $200 \mathrm{~d}$ of frost-free days, drying and multipurpose cultivars, from early to late in maturation, would grow and produce well. As trees in these cultivar trials mature and produce more fruit, especially at Los Lunas and Leyendecker, more research on drying will be conducted. As for the exact growing season length, due to large temperature fluctuations in central and northern New Mexico, new jujube growth may not be affected at 0 to $-0.5^{\circ} \mathrm{C}$; we would need more time and data to determine which temperature threshold should be used for the length of the growing season calculation: $0,-1$, or $-2{ }^{\circ} \mathrm{C}$. We will fine-tune the recommendations as more data become available. 
Table 4. Jujube fruit size, weight, and soluble solids content (SS) at different locations (AL-Alcalde, LL-Los Lunas, LK-Leyendecker).

\begin{tabular}{|c|c|c|c|c|c|c|c|c|c|c|c|c|}
\hline \multirow[b]{2}{*}{ Cultivar } & \multicolumn{2}{|c|}{ Fruit length $(\mathrm{mm})$} & \multicolumn{2}{|c|}{ Fruit width $(\mathrm{mm})$} & \multicolumn{2}{|c|}{ Avg wt (g) 2017} & \multicolumn{2}{|c|}{ SS (\%) 2017} & \multicolumn{2}{|c|}{ Avg wt (g) 2019} & \multicolumn{2}{|c|}{ SS (\%) 2019} \\
\hline & $\mathrm{AL}$ & LL & $\mathrm{AL}$ & LL & $\mathrm{AL}$ & LL & $\mathrm{AL}$ & LL & $\mathrm{AL}$ & LK & $\mathrm{AL}$ & LK \\
\hline Don P & 45.8 & 43.6 & 30.7 & 30.3 & 17.8 & 16.2 & 31.8 & 35.3 & 17.5 & & 31.1 & \\
\hline Jinsi 3 & 35.7 & 35.6 & 26.5 & 27.8 & 11.4 & 10.5 & 28.3 & 29.9 & 10.9 & 16.2 & 27.9 & 36.3 \\
\hline Jinsi 4 & 27.1 & 31.2 & 18.7 & 22.5 & 6.6 & 7.7 & 28.7 & 36.9 & 4.2 & & 27.8 & - \\
\hline Jixin & 35.9 & 35.3 & 35.1 & 35.7 & 11.0 & 10.6 & 32.3 & 33 & 11.5 & 12.5 & 36.2 & 36.8 \\
\hline KFC & 38.7 & 39 & 26.1 & 28 & 11.2 & 12.6 & 30.7 & 32.7 & 9.4 & 13.6 & 28.2 & 30.7 \\
\hline Lang & 45.7 & 46.3 & 32.2 & 33.7 & 18.2 & 17.6 & 31.4 & 29.8 & 15.1 & & 27.2 & - \\
\hline Pitless & 28.6 & 27.4 & 20.8 & 20.9 & 4.9 & 5 & 36.2 & 42.3 & 6.0 & 5.8 & 31.1 & 35.7 \\
\hline Sherwood & 40.6 & 40.2 & 30.4 & 31.2 & 15.9 & 16.6 & 27.4 & 37.8 & 11.8 & & 25.5 & - \\
\hline Shuimen & 39.0 & 39.6 & 27.4 & 28.5 & 11.7 & 9.9 & 28.7 & 32.2 & 13.1 & 15.6 & 29.6 & 28.2 \\
\hline Sihong & 36.0 & 36.5 & 31.8 & 39.7 & 16.0 & 14 & 30.6 & 35.2 & 15.2 & 17.2 & 32.7 & 36.3 \\
\hline Xiangzao & 40.2 & 40.3 & 32 & 34.9 & 16.9 & 18 & 28.2 & 29.4 & 12.6 & 19.1 & 26.3 & 32.9 \\
\hline
\end{tabular}

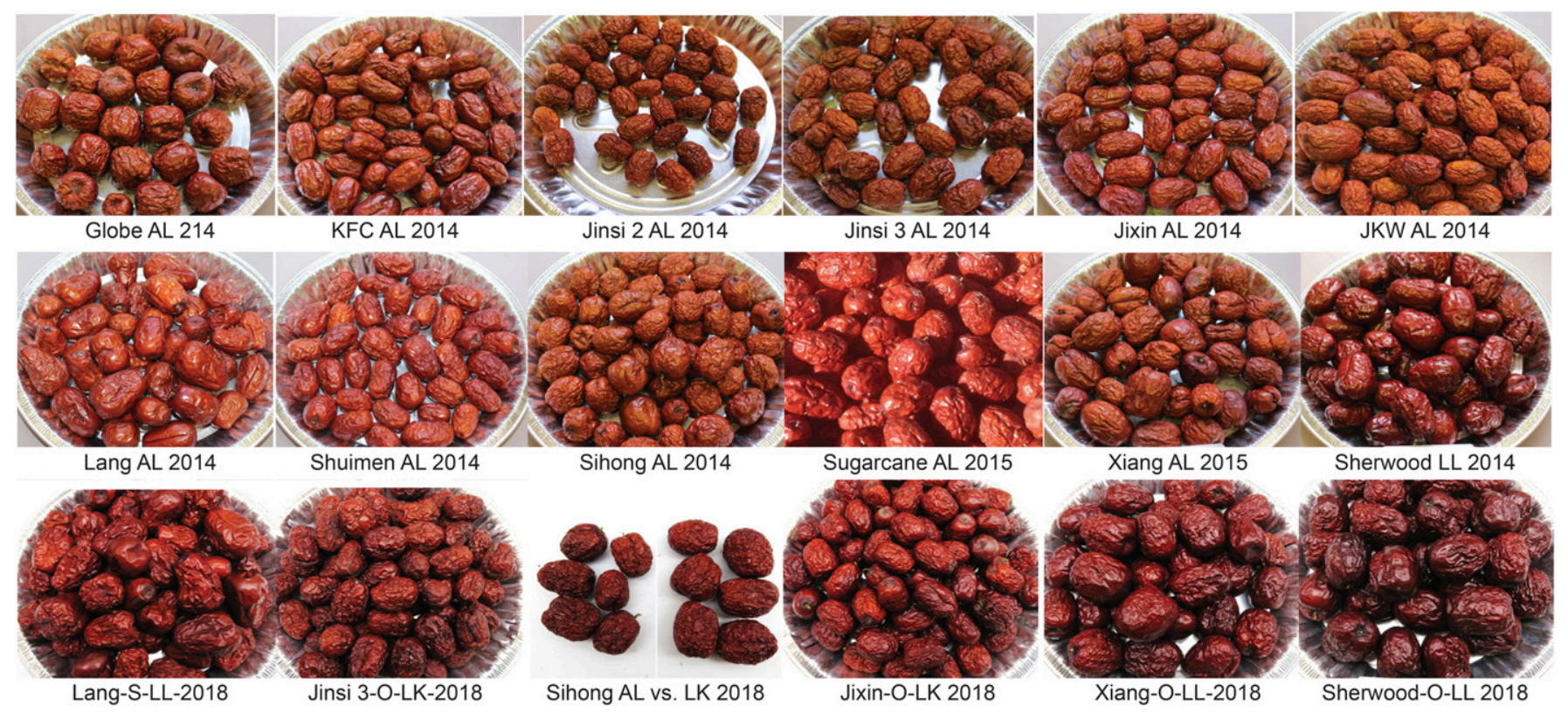

Fig. 3. Cultivar dry fruit pictures. $\mathrm{AL}=$ Alcalde; $\mathrm{LL}=\mathrm{Los}$ Lunas; $\mathrm{LK}=$ Leyendecker, $\mathrm{O}=$ oven drying, $\mathrm{S}$ or no extra mark $=$ sun drying. Most pictures in the first two rows were samples from Alcalde in 2014, which had a relatively longer growing season than average.

Fruit set management. We noticed poor fruit set for 'Sherwood', 'Xiangzao', 'Jixin', 'Sandia', and 'GA866' at Alcalde, whereas 'KFC' and 'Chaoyang' set heavily at all locations. 'Sihong' has large trees at all locations, but fruit set is limited. ' $\mathrm{JKW}$ ' and 'Xiangzao' were productive at Leyendecker.

In China, jujube cultivars are classified into three types based on their temperature requirement at fruit set period: high temperature type, which needs daily average temperatures of $25^{\circ} \mathrm{C}$ or higher to set fruit; low temperature type, which requires daily average temperatures of $21^{\circ} \mathrm{C}$ or higher; and the third type is between those two and requires daily average temperatures of $23^{\circ} \mathrm{C}$ or higher (Guo et al., 2002). There is no fruit set information for jujube cultivars in the United States. It is still not clear whether poor fruit set is due to temperature requirements, nutri- ent/cultural management, or a cultivar's own genetic characteristics. The fruit set for these cultivar trials was natural without cultural intervention except Alcalde. Trees at Alcalde had water spray during bloom time since year 3 which may increase fruit set. It could be the cultivar's own characteristics; for example, some cultivars are more precocious than others. ' $\mathrm{Li}$ ' is very precocious and productive, but 'Sherwood' did not produce heavily in the first 3 to 5 years after planting. Later, 'Sherwood' produced well at Los Lunas (unpublished data). Another factor influencing fruit set is temperature requirement. Some cultivars may need higher temperatures to set fruit, whereas 'KFC' and 'Chaoyang' can set well at relatively lower temperatures. Cultivars with a low temperature requirement are suitable for a wide range of locations, whereas the high-temperature cultivars are suitable for more southern locations, or some cultural practices can be applied to improve their fruit set, such as girdling or gibberellin spray, which are commonly used in China (Guo and Shan, 2010).

Cultivar recommendation and fruit uses. 'Banzao', 'Chaoyang', 'Pitless', 'Sugarcane', 'Lang', and 'Junzao' are acceptable drying cultivars in northern New Mexico, and the drying quality varied from year to year depending on the length of the growing season. 'KFC' is good for fresh eating but not for drying at Alcalde. 'Sherwood', 'Globe', 'JKW', and 'Xiangzao' are not recommended for northern New Mexico. All 19 cultivars performed well at Los Lunas except in 2019. At Leyendecker, drying, multipurpose, and early-, mid-, and late-season cultivars all performed well with higher soluble solids and larger fruit size than in northern New 
Mexico. Growers can select cultivars based on their needs and local climate conditions. With plenty of current year's new growth in southern locations, the yield would be more reliable. Growers may consider multiple harvests because the fruit from old branches would mature earlier than fruit on current year's new growth. Home gardeners have fewer considerations than commercial growers and can plant any cultivar recommended here.

Fruit size is another factor to consider for commercial production. Large-fruited cultivars such as Sherwood, Xiangzao, Lang/ Junzao/Don Polenski, and JKW are more appealing. But small-fruited cultivars are not inferior, and they can have their own special uses. 'Jinsi 2', 'Jinsi 4', and 'Pitless' are suitable in various kinds of teas as whole fruit. 'Pitless' has a special advantage with exposed seeds because the pit is incomplete. Consumers can get the benefit of both fruit and seeds. Those small-fruited cultivars may have a local or niche market. We noticed some fruit splitting/cracking at maturation time. If growers are focusing on the dry fruit market, precipitation around maturation time should be closely monitored, or rain protection equipment may be needed.

\section{Literature Cited}

Chen, L., Y. Mao, and Z. Dong. 2008. Research progress of storage and fresh keeping of fresh eating jujubes. Deciduous Fruits 2008(2):2933. (in Chinese).

Guo, Y., G. Shan, and M. Yang. 2002. Zoning cultivation of jujube in China. China Fruits 2002(4):44-46. (in Chinese).

Guo, Y. and G. Shan. 2010. The chinese jujube. Shanghai Scientific and Technical Publishers, Shanghai, China (in Chinese).

Huang, J., R. Heyduck, R. Richins, D. VanLeeuwen, M.A. O'Connell, and S. Yao. 2017. Jujube cultivar vitamin $\mathrm{C}$ profile and nutrient dynamics during maturation. HortScience 52:859-867, doi: 10.21273/HORTSCI11945-17.

Li, M. and X. Wen. 2008. Achievements of studies of fresh keeping techniques of Dongzao jujube. Chinese Agr. Sci. Bul. 25:92-95. (in Chinese).

Li, X., J. Huang, and W. Gao. 2005. A study on highquality production regions of dry Chinese jujube in China. J. Fruit Sci. 22:620-625. (in Chinese).

Liu, M. 2008. China jujube development report. China Forestry Publishing House, Beijing, China (in Chinese).

Liu, M. and M. Wang. 2009. Germplasm resources of Chinese jujube. China Forestry Publishing House, Beijing, China (in Chinese).

Meyer, F.N. 1916. China a fruitful field for plant exploration, p. 205-224. In: USDA Yearbook 1915. U.S. Dept. Agr., Washington, DC. 30 July 2020. <http:// naldc.nal.usda.gov/download/IND43843025/PDF>.

New Mexico Climate Center. 2020. Weather stations and data retrieval. 30 July 2020. $<$ https:// weather.nmsu.edu/coop/request/station/290245/ data/>.

Thomas, C.C. 1927. Chinese jujube in southwestern United States, p. 212-215. In: USDA yearbook of agriculture 1926. U.S. Dept. Agr., Washington,
DC. 30 July 2020. <http://naldc.nal.usda.gov/ download/IND43842740/PDF>.

U.S. Department of Agriculture. 2012. USDA plant hardiness zone map. 30 July 2020. $<$ https://planthardiness.ars.usda.gov/PHZMWeb/ Default.aspx $>$.

Wang, H., S. Cui, and Y. Wang. 2008. Storage and fresh keeping techniques of Zhanhuadongzao. Northern Hort. 2008(1):232-234. (in Chinese).

Western Regional Climate Center. 2020. New Mexico Climate Summaries. 30 July 2020. $<$ https:// wrcc.dri.edu/summary/climsmnm.html $>$.

Yao, S. 2013. Past, present, and future of jujubesChinese dates in the United States. HortScience 48:672-680, doi: 10.21273/HORTSCI.48.6.672.

Yao, S., J. Huang, and R. Heyduck. 2015. Jujube flowering and fruiting in the southwestern United States. HortScience 50:839-846, doi: 10.21273/HORTSCI.50.6.839.

Yao, S. 2018. Jujube phenology, pollen germination and two unique germplasm resources in New Mexico. HortScience 53:23-27, doi: 10.21273/HORTSCI12512-17.

Yao, S. and R. Heyduck. 2018. Ornamental jujube cultivar evaluation in the southwestern United States. HortTechnology 28:557-561, doi: 10.21273/HORTTECH04073-18.

Yao, S. 2019. Jujube training and pruning basics. NMSU Cooperative Extension Service publication H-337. 31 Aug. 2020. <https://aces.nmsu. edu/pubs/h/H337/welcome.html>.

Yao, S., R. Heyduck, and S. Guldan. 2019. Early performance of fresh eating jujube cultivars in the southwestern United States. HortScience 54:19411946, doi: 10.21273/HORTSCI14312-19. 